\title{
FORMULASI EKSTRAK KULIT BATANG NANGKA (Artocarpus heterophyllus Lamk.) DIDALAM SABUN EMULSI MINYAK KEDELAI BERSCRUB POLIETILEN
}

\author{
Siti Umrah Noor, Dadan Teja Permana \\ Fakultas Farmasi Universitas Pancasila \\ E-mail: siti_umrahnoor@yahoo.com
}

\begin{abstract}
ABSTRAK
Ekstrak kulit batang nangka mengandung flavanoid artocarpanon yang memiliki aktivitas penghambatan enzim tirosinase sehingga berpotensi sebagai pemutih kulit. Penelitian ini bertujuan untuk menghasilkan formula sabun emulsi minyak kedelai dengan ekstrak etanol kulit batang nangka, butiran scrub dan variasi konsentrasi acrylates crosspolymer $2 \%, 2,5 \%$, dan $3 \%$ yang stabil secara fisik. Ekstrak dibuat menggunakan metode maserasi dengan etanol $96 \%$. Sediaan diuji mutu fisiknya dan diuji stabilitas dipercepat selama 4 minggu pada penyimpanan suhu kamar dan suhu $40^{\circ} \mathrm{C}$. Hasil penelitian menunjukkan bahwa sediaan memiliki karakteristik fisik berupa cairan kental berwarna coklat muda beraroma chamomile, tipe emulsi M/A, derajat sedimentasi 1, volume busa setelah pengocokan 2 menit dalam air suling $72 \mathrm{~mL}$ dan dalam air sadah $24 \mathrm{~mL}$. Tegangan permukaan $(32,47 \pm 0,45)$ dyne/cm, pH sekitar 6,26; viskositas $(7016,67 \pm 28,87) \mathrm{cPs}$, sifat alir tiksotropik plastis, ukuran globul minyak setelah 4 minggu penyimpanan meningkat $(42,8431 \mu \mathrm{m}$ menjadi 59,6487 $\mu \mathrm{m})$. Dapat disimpulkan bahwa formula terbaik adalah yang memiliki konsentrasi acrylates crosspolymer sebesar $3 \%$.
\end{abstract}

Kata kunci: ekstrak kulit batang nangka, sabun emulsi, butiran scrub, acrylates crosspolymer, stabilitas fisik.

\begin{abstract}
Extract of jackfruit cortex contain flavanoid such as artocarpanon which have activity as tyrosinase inhibitors so that potentially as a skin whitening. The study aimed to obtain a formulation of soybean oil emulsion soaps of ethanolic Jackfruit cortex extract with polyethylene scrub and variety of acrylates crosspolymer $2 \%, 2,5 \%$, and $3 \%$ with good physical characteristic. Extracts were prepared using maceration method with ethyl alcohol 96\%. Emulsion soap were tested physical characteristic and the stability test were carried out under two temperatures, room and $40^{\circ} \mathrm{C}$ and observed within 4 weeks. The results showed that the emulsion soap have brown pale, viscous liquid and chammomile's fragrance, the emulsion type was $\mathrm{O} / \mathrm{W}$, the sedimentation level was 1 , foam volume after being shaked for 2 minutes were $72 \mathrm{~mL}$ in destilated water and $24 \mathrm{~mL}$ in hard water with stable foams. The surface tension value was $(32,47 \pm 0,45)$ dyne/cm with $\mathrm{pH} \pm 6,26$. Based on the stability test, the viscousity was $(7016,67 \mathrm{cPs} \pm 28,87) \mathrm{cPs}$, the rheology was thixotropic plastic, the droplet size in room temperature was $42,8431 \mu \mathrm{m}$ until 59,6487 $\mu \mathrm{m}$. The conclusion is the best formula which contains $3 \%$ acrylates crosspolymer.
\end{abstract}

Keywords: extract of jackfruit cortex, emulsion soap, polyethylene scrub, acrylates crosspolymer, physical stability 


\section{PENDAHULUAN}

Melanin merupakan suatu pigmen yang dibentuk oleh sel melanoblast yang terdapat di lapisan basal epidermis yang berguna untuk memberikan warna pada kulit, dan secara alami sebagai protektor untuk melindungi kulit dari sinar UV dan panas. Namun bila terjadi peningkatan melanin akan menyebabkan hiperpigmentasi.

Menurut Chang D. L. (2005) didalam kulit terdapat enzim tirosinase yang berguna mengkatalisis reaksi dalam biosintesis melanin, yaitu hidroksilasi L-tirosin menjadi L-dopa dan oksidasi L-dopa menjadi dopakuinon. Polimerisasi secara spontan pada dopakuinon membentuk dopakrom yang kemudian menjadi melanin (1). Penghambatan aktivitas enzim tirosinase merupakan cara yang tepat untuk mengatasi pembentukan melanin secara berlebihan. Berbagai sediaan kosmetik perawatan kulit telah banyak mengaplikasikan inhibitor tirosinase sehingga kulit menjadi putih dan cerah. Penggunaan zat pemutih kulit sintetik untuk kosmetika seperti merkuri sudah dilarang, karena zat tersebut bersifat toksik yang membahayakan kulit, oleh karena itu pemanfaatan bahan alam yang memiliki potensi inhibitor tirosinase menjadi pilihan tepat.

Penelitian yang dilakukan oleh Juwita (2011) pada ekstrak kulit batang nangka memiliki aktivitas sebagai inhibitor tirosinase dengan nilai IC $_{50}$ sebesar 142,37 ppm. Ekstrak tersebut diformulasikan kedalam sediaan dengan konsentrasi sebesar 1,5\% dan $2,0 \%$ dan menunjukkan aktivitas penghambatan tirosinase sebesar 10,64\% (28,29 ppm) dan 11,34\% (30,31 ppm) (2). Dalam penelitian Linda (2012) (3), acrylates crosspolymer (aqualose- $2^{\circledR}$ ) pada konsentrasi $1,5 \%$ yang digunakan untuk mendispersikan butiran scrub tidak terdispersi setelah sediaan sabun emulsi disimpan selama 1 bulan pada suhu kamar.

Berdasarkan hal tersebut, pada penelitian ini digunakan ekstrak kulit batang nangka sebesar 2\% yang akan ditambahkan kedalam sabun emulsi minyak kedelai yang mengandung scrub dan konsentrasi acrylates crosspolymer ditingkatkan dari 2\%, 2,5\% dan $3 \%$ dengan tujuan agar didapatkan formula yang memenuhi parameter mutu fisik. Acrylates crosspolymer memiliki (shear-thinning) serta memiliki kemampuan tinggi dalam menstabilkan bahan-bahan tidak larut karena adanya proses cross-linking, serta memberikan kinerja yang efektif pada kisaran $\mathrm{pH}$ yang luas dengan efisiensi viskositas pada pH 5 (3). Acrylates crosspolymer hanya sedikit meningkatkan viskositas sediaan, oleh karena itu ditambahkan HPMC. Kulit batang nangka memilki kandungan flavonoid artocarpanon yang berguna untuk menghambat pembentukan melanin yang berlebihan, dalam hal ini digunakan etanol $96 \%$ guna menyari artocarpanon dengan metode maserasi.

Sabun yang akan dibuat berupa sabun emulsi dengan minyak kedelai sebagai fase minyak. Sebagai pembersih digunakan kombinasi surfaktan golongan anionic, amfoterik dan nonionic yaitu natrium lauril eter sulfat, kokamidopropil betain dan kokamido DEA yang memiliki busa cukup banyak dan stabil. Minyak kedelai mengandung asam-asam lemak tak jenuh yang baik untuk menjaga kelembutan kulit, adanya emulsi yang stabil menggunakan TEA stearat dan TEA laurat sebagai emulsifying agent pada sediaan sabun dapat memberikan efek oklusi sehingga mengurangi hilangnya kelembaban pada permukaan kulit (4). Pada formula ditambahkan zat yang bersifat abrasif yaitu butiran scrub yang dapat membersihkan kotoran pada kulit secara mekanik. Digunakan scrub polietilen sintetik yang bersifat hydrophob sehingga membutuhkan gliserin sebagai wetting agent. Scrub sintetik lebih stabil dibandingkan scrub alami serta memiliki keunggulan dapat membersihkan kulit secara mekanik dengan menghilangkan sel-sel kulit mati. Poliquaternium-10 ditambahkan kedalam formula agar terbentuk sabun emulsi berscrub yang lembut, serta nyaman digunakan karena dapat mengurangi rasa berminyak (oily feeling). 


\section{METODE PENELITIAN}

\section{Bahan}

Kulit batang nangka (Balittro), natrium lauril eter sulfat dan kokamidopropil betain (BASF, Amerika Serikat), kokamid DEA (Stepan Phillippines, Inc), polietilen (Honeywell International Inc, Amerika Serikat), acrylates crosspolymer (Lubrizol, Amerika Serikat), poliquaternium-10 (Miwon Commercial Co, Ltd, Korea). magnesium karbonat, kalsium karbonat.

\section{Peralatan}

Timbang analitik (AND, GR 200), oven (Memmert), tensiometer Du-Nouy (Krass), viskometer (Brookfield , LV), $\mathrm{pH}$ meter (methrohm, 620), pengaduk (Eurostar), mikroskop (Objective \& eyepiece micrometer olympus, model CHS), Rotary vacum evaporator (Buchi), lensa okuler mikrometer, alat-alat gelas (Pyrex)

\section{Prosedur}

\section{Pembuatan ekstrak kulit batang nangka (Artocarpus heterophyllus)}

500 gram serbuk kulit batang nangka yang sudah dikeringkan di bawah sinar matahari langsung ditimbang, dan dimaserasi dengan etanol 96\% sambil diaduk dengan pengaduk mekanik lalu disaring. Maserasi dilakukan sebanyak 3 kali. Maserat dikumpulkan, dipekatkan dengan vakum rotavapor hingga diperoleh ekstrak kental.

\section{Pemeriksaan senyawa flavonoid}

1 gram serbuk atau $\pm 200 \mathrm{mg}$ ekstrak kental ditambahkan $100 \mathrm{~mL}$ air panas, didihkan selama 5 menit, disaring, filtrat digunakan sebagai larutan percobaan, ditambahkan serbuk atau lempeng magnesium secukupnya dan $1 \mathrm{~mL}$ HCL pekat, ditambahkan $2 \mathrm{~mL}$ amil alkohol, dikocok kuat, dibiarkan memisah, terbentuk warna dalam larutan amil alkohol menunjukkan adanya senyawa flavonoid.

\section{Formula sabun emulsi minyak kedelai berscrub ekstrak kulit batang nangka}

Tabel 1. Formula sabun emulsi minyak kedelai berscrub ekstrak kulit batang nangka

\begin{tabular}{|c|c|c|c|c|}
\hline \multirow{2}{*}{ Bahan } & \multicolumn{4}{|c|}{ Formula (\%b/v) } \\
\cline { 2 - 5 } & $\begin{array}{c}\text { I } \\
\text { (blangko) }\end{array}$ & II & III & IV \\
\hline Ekstrak kulit batang nangka & 2 & 2 & 2 & 2 \\
\hline Minyak kedelai & 5 & 5 & 5 & 5 \\
\hline Na lauril eter sulfat & 10 & 10 & 10 & 10 \\
\hline Kokamidopropil betain & 5 & 5 & 5 & 5 \\
\hline Kokamide DEA & 5 & 5 & 5 & 5 \\
\hline Asam stearat & 4 & 4 & 4 & 4 \\
\hline Asam laurat & 2 & 2 & 2 & 2 \\
\hline Trietanolamin & 3 & 3 & 3,5 & 4 \\
\hline Acrylates crosspolymer & 2 & 2 & 2,5 & 3 \\
\hline Polietilen & 3 & 3 & 3 & 3 \\
\hline HPMC & 1 & 1 & 1 & 1 \\
\hline Gliserin & 5 & 5 & 5 & 5 \\
\hline Poliquaternium-10 & 0,2 & 0,2 & 0,2 & 0,2 \\
\hline
\end{tabular}




\begin{tabular}{|c|c|c|c|c|}
\hline Isotiazolin & 0,05 & 0,05 & 0,05 & 0,05 \\
\hline BHA & 0,02 & 0,02 & 0,02 & 0,02 \\
\hline Larutan asam sitrat & 0,75 & 1,20 & 1,50 & 1,75 \\
\hline $\begin{array}{c}\text { Na metabisulfit } \\
(0,1 \% \text { terhadap ekstrak kulit batang } \\
\text { nangka) }\end{array}$ & 0,1 & 0,1 & 0,1 & 0,1 \\
\hline Parfum & 1 & 1 & 1 & 1 \\
\hline Aqua demineralisata ad & 100 & 100 & 100 & 100 \\
\hline
\end{tabular}

\section{Pembuatan sabun emulsi minyak kedelai berscrub ekstrak kulit batang nangka}

1) Asam stearat dilebur diatas penangas air pada suhu $70^{\circ} \mathrm{C}$ dan setelah melebur dimasukkan minyak kedelai (diaduk) dan BHA (dilarutkan) (fase minyak

2) Asam laurat dengan sebagian gliserin dilebur di atas penangas air pada suhu $70^{\circ} \mathrm{C}$ (fase minyak 2)

3) TEA dicampurkan dengan sebagian air bersuhu $70^{\circ} \mathrm{C}$ kemudian dijaga suhunya (fase air)

4) Fase minyak 1 dicampurkan dengan fase minyak 2 kemudian dimasukkan fase air dan diaduk ad terbentuk emulsi menggunakan stirrer (campuran 1)

5) Kokamidopropil betain ditambahkan dengan kokamide DEA kemudian dimasukkan ke dalam natrium lauril eter sulfat kemudian dicampurkan dengan sebagian air (campuran 2)

6) HPMC yang telah dikembangkan sebelumnya ditambahkan kedalam campuran 2 (campuran 3)

7) Campuran 1 ditambahkan dengan campuran 3 kemudian diaduk dengan stirrer (sabun emulsi)

8) Parfum ditambahkan kedalam sabun emulsi yang sudah terbentuk Acrylates crosspolymer dinetralkan dengan trietanolamin dengan perbandingan (1:1) sampai terbentuk basis gel dalam beaker glass

9) Serbuk polietilen yang telah dibasahi dengan gliserin kemudian didispersikan dengan basis gel hingga sempurna (campuran 4)

10) Campuran 4 dimasukkan ke dalam sabun emulsi yang sudah terbentuk, diaduk sampai homogen (campuran 5)

11) Poliquaternium-10 dilarutkan dalam air kemudian ditambahkan dengan campuran 5 diaduk sampai homogen

12) Isothiazolin ditambahkan kedalam campuran 5 diaduk sampai homogen

13) Ekstrak kulit batang nangka yang telah dicampur dengan $\mathrm{Na}$ metabisulfit $0,1 \%$ dicampurkan dengan sisa gliserin kemudian ditambahkan sisa aqua demin dan dimasukkan ke dalam sabun emulsi yang sudah terbentuk

14) Amati $\mathrm{pH}$ jika perlu ditambahkan asam sitrat sampai mendekati $\mathrm{pH}$ fisiologis kulit

15) Sediaan dimasukkan kedalam wadah, kemudian dilakukan evaluasi

\section{Uji Viskositas dan sifat alir}

Sabun cair ditempatkan dalam wadah gelas, spindel yang sesuai diturunkan hingga batas spindel tercelup dalam sediaan. Nyalakan alat, biarkan spindel berputar pada kecepatan tertentu sampai jarum menunjukkan skala tetap. Angka skala dicatat, kemudian dikalikan dengan faktor pada tabel sesuai tipe viskometer yang digunakan. Dengan beberapa seri rpm yang digunakan, diperoleh nilai viskositas pada berbagai rpm. Sifat alir ditentukan dengan membuat kurva antar gaya $\left(\right.$ dyne $\left./ \mathrm{cm}^{2}\right)$ yang diperoleh dari skala dikalikan konstanta alat (KV) sebagai sumbu y, kemudian diplot pada kertas grafik. 


\section{Uji tegangan permukaan}

Larutan sediaan 1\% diukur menggunakan tensiometer metode cincin Du Nuoy. Pengukuran dilakukan sebagai berikut:

1) Sediaan dimasukkan dalam cawan petri dan diletakkan pada meja sampel

2) Dipanaskan cincin pada kait sistem pengukuran tanpa kontak dengan cairan uji

3) Meja sampel diatur sehingga cincin tercelup sedalam 2-3 mm dalam sediaan

4) Gaya diubah dan diatur sampai titik nol, kemudian dengan memutar pengatur meja sampel sambil tetap menjaga jarum petunjuk cahaya tetap berada di tengah-tengah cermin

5) Gaya ditambahkan terus-menerus sampai film pada cairan permukaan cairan terangkat. Skala dibaca dalam dyne/cm

6) Faktor koreksi cincin dihitung dengan bantuan rumus sebagai berikut:

$$
\text { Faktor koreksi }=0,8759+\frac{(0,0009188 \times \text { OSRuk })}{D}
$$

Keterangan: OSRuk : tegangan permukaan yang belum terkoreksi

D : bobot jenis cairan uji

F : faktor koreksi tegangan permukaan

7) Harga yang terukur dikalikan dengan faktor yang menghasilkan tegangan permukaan absolut: $O s$ abs $=F x$ OS Ruk

Keterangan: Os abs: tegangan permukaan absolut

Uji volume dan stabilitas busa dalam air suling dan air sadah

Pengukuran dilakukan dengan metode Ross Miles Test

a) Ditimbang 0,1 gram sabun, dicampur dengan air suling ad $100 \mathrm{~mL}$

b) Dimasukkan ke dalam gelas ukur tertutup $100 \mathrm{~mL}$ dengan diameter 2,7 $\mathrm{cm}$ dan dikocok dengan membalikkan tabung sedimentasi selama 2 menit, volume busa yang terbentuk diamati.

Untuk pengukuran stabilitas busa, 5menit kemudian volume dicatat kembali.

Pengukuran tinggi dan stabilitas busa dalam air sadah serupa dengan pengukuran tinggi busa yang dibuat dengan melarutkan 2,33 gram kalsium karbonat dan 1,16 gram magnesium karbonat dan ditambahkan asam klorida tetes demi tetes hingga larut, ditambahkan air suling sampai $100 \mathrm{~mL}$.

\section{HASIL DAN PEMBAHASAN}

\section{Hasil ekstraksi kulit batang nangka}

Kulit batang nangka diperoleh dari Badan Penelitian Tanaman Obat dan Aromatis (Balittro), hasil determinasi dilakukan di Herbarium Bogorinse, LBN, LIPI Cibinong

Tabel 2. Hasil ekstraksi kulit batang nangka

\begin{tabular}{|c|l|l|c|}
\hline No & \multicolumn{1}{|c|}{ Pengujian } & \multicolumn{1}{c|}{ Hasil } & Ket \\
\hline 1 & Bobot serbuk & 6550 & $\mathrm{~g}$ \\
\hline 2 & Vol penyari & 45000 & $\mathrm{~mL}$ \\
\hline 3 & Vol ekstrak cair & 43700 & $\mathrm{~mL}$ \\
\hline 4 & Vol ekstrak kental & 253,72 & $\mathrm{~g}$ \\
\hline 5 & Warna ekstrak kental & Coklat kehitaman & \\
\hline
\end{tabular}




\begin{tabular}{|c|c|c|c|}
\hline 6 & Bau ekstrak kental & Khas aromatis & \\
\hline 7 & pH ekstrak kental & 6,18 & \\
\hline 8 & Bj ekstrak kental & 0,9890 & $\mathrm{~g} / \mathrm{cm}^{3}$ \\
\hline 9 & Rendemen & 3,87 & $\%$ \\
\hline 10 & $\begin{array}{l}\text { Ketercampuran dalam air, gliserin, } \\
\text { etanol, larutan sabun }\end{array}$ & larut & \\
\hline 11 & Uji flavanoid & Lapisan jingga muda (amil alcohol) & positif \\
\hline
\end{tabular}

\section{Hasil Evaluasi mutu fisik}

Hasil uji mutu fisik yang meliputi: organoleptk/homogenitas, viskositas/sifat alir, ukuran globul, tipe emulsi, bobot jenis, tegangan permukaan, volume/stabilitas busa, volume sedimentasi dan $\mathrm{pH}$ terhadap semua formula memenuhi parameter mutu fisik. Semua formula dilanjutkan dengan uji stabilitas mutu fisik selama 4 minggu yang disimpan pada suhu kamar dan suhu $40^{\circ} \mathrm{C}$ dan diuji setiap minggu.

\section{HASIL UJI STABILITAS MUTU FISIK SELAMA 4 MINGGU}

\section{Hasil Uji Stabilitas Organoleptik dan homogenitas}

Organoleptik semua formula tidak terjadi perubahan bentuk, warna, dan bau. Pada minggu ke-1 pada formula I terjadi perubahan fisik seperti pemisahan fase dan perubahan warna. Formula II - IV sampai minggu ke-4 pada kedua suhu tetap stabil. Pengujian stabilitas berikutnya untuk formula I tidak dilanjutkan. Semua formula yang dihasilkan homogen, karena acrylates crosspolymer memiliki rantai polimer yang digabung oleh ikatan kimia membentuk crosslink (ikatan silang). Scrub polietilen merupakan jenis polimer termoplastik, sehingga dengan adanya acrylates crosspolymer menjadi kompatibel dan terdispersi dengan baik dalam jeratan ikatan silang.

\section{Hasil Uji Stabilitas Viskositas dan Sifat Alir}

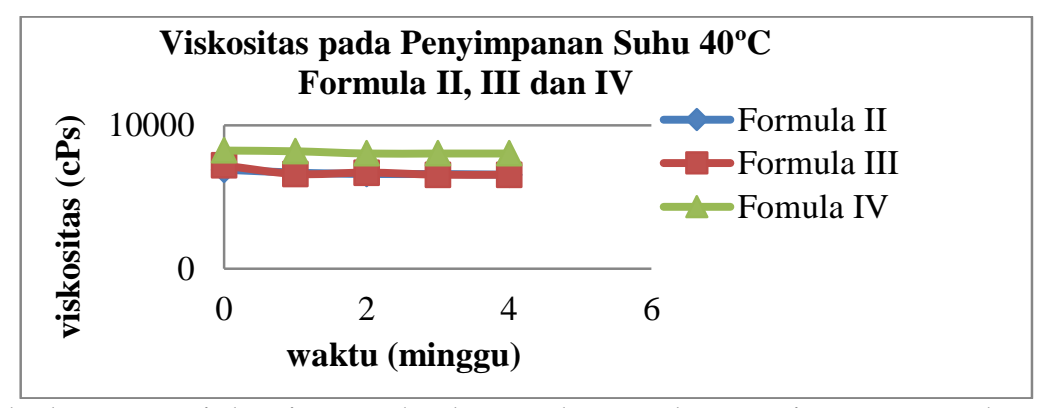

Gambar 1. Grafik hubungan viskositas terhadap waktu pada penyimpanan suhu $40^{\circ} \mathrm{C}$ 


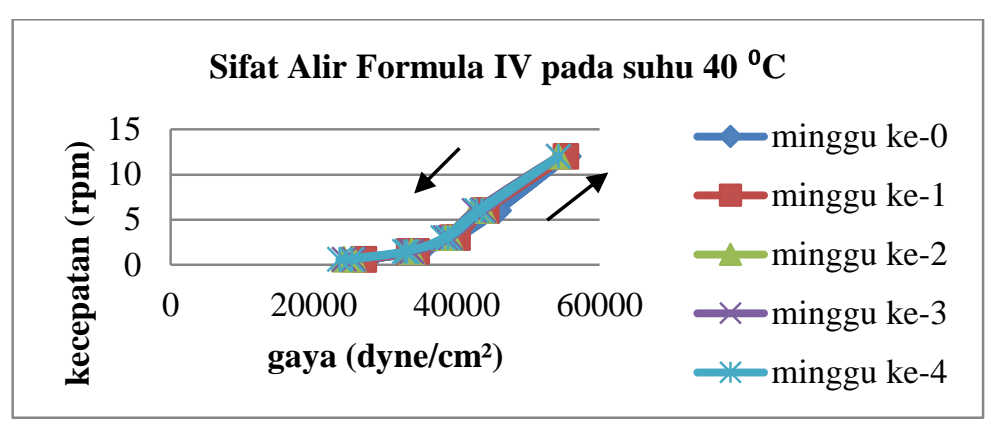

Gambar 2. Grafik sifat alir formula IV pada penyimpanan suhu $40^{\circ} \mathrm{C}$

Hasil viskositas formula II, III, dan IV pada suhu kamar menunjukkan nilai berturut-turut sebesar 6900-7000 cPs; 6750-7250 cPs; dan 8150-8350 cPs. Hal ini menunjukkan bahwa dengan penambahan konsentrasi acrylates crosspolymer maka viskositas sediaan akan meningkat. Hasil viskositas formula II, III, dan IV pada suhu $40^{\circ} \mathrm{C}$ (Gambar 1) menunjukkan penurunan viskositas dengan nilai viskositas berturut-turut sebesar 6550-6900 cPs; 6550-7200 cPs; dan 8050-8250 cPs. Adanya peningkatan konsentrasi acrylates crosspolymer menunjukkan adanya perubahan viskositas yang terjadi. Berdasarkan hasil ANVA dua arah menunjukkan bahwa adanya perbedaan bermakna terhadap penyimpanan pada suhu kamar dan suhu $40^{\circ} \mathrm{C}$. Perbedaan ini karena berlakunya persamaan Arrhenius, yaitu tiap peningkatan suhu $10^{\circ} \mathrm{C}$ dapat meningkatkan laju reaksi kimia, salah satunya penurunan viskositas.

Formula II memiliki sifat alir tikostropik pseudoplastis, yaitu kurva menurun berada disebelah kiri kurva menaik. Formula III dan Formula IV (Gambar 2) menunjukkan sifat alir tikostropik plastis, karena mengandung scrub yang menghasilkan sistem terflokulasi. Sabun emulsi berscrub mengandung ekstrak mudah dituang, serta akan tetap kembali ke bentuk semua dengan partikel yang masih tetap terdispersi homogen.

\section{Hasil Uji Stabilitas Ukuran Globul Minyak}

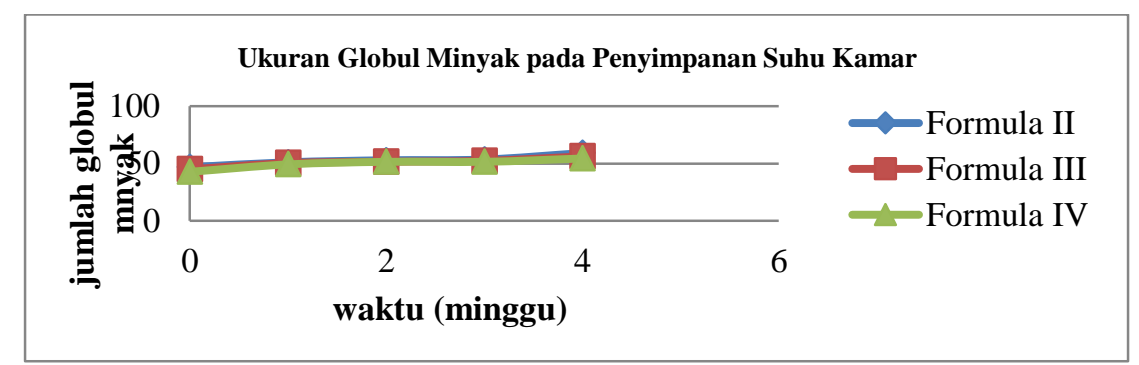

Gambar 3. Grafik hubungan ukuran globul minyak terhadap waktu pada penyimpanan suhu kamar 


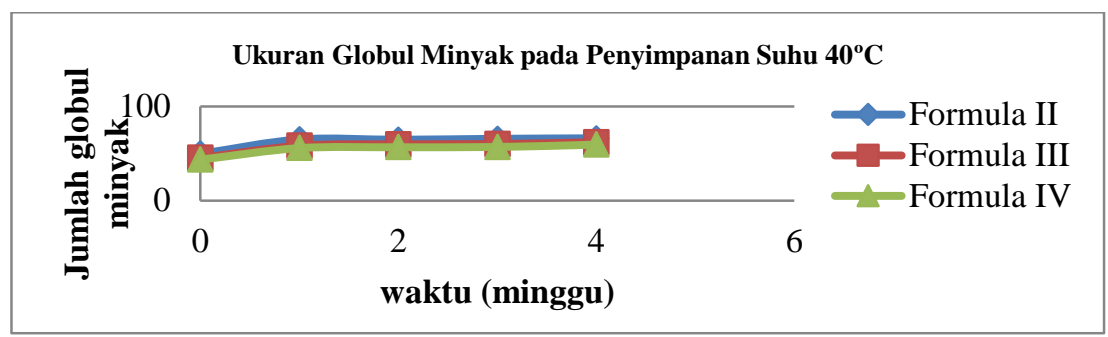

Gambar 4. Grafik hubungan ukuran globul minyak terhadap waktu pada penyimpanan suhu $40^{\circ} \mathrm{C}$

Pada hasil uji mutu fisik terlihat adanya penurunan ukuran globul minyak pada formula II sampai dengan formula IV pada suhu kamar maupun suhu $40^{\circ} \mathrm{C}$. Ukuran globul formula II sampai dengan IV berturut-turut pada suhu kamar yaitu 46,7829 $\mu \mathrm{m}$, $45,1385 \mu \mathrm{m}$, dan $42,8431 \mu \mathrm{m}$. Tetapi berdasarkan hasil uji stabilitas pada penyimpanan suhu kamar dan suhu $40^{\circ} \mathrm{C}$ terjadi peningkatan ukuran globul minyak. Ukuran globul pada penyimpanan suhu kamar (Gambar 3) pada formula II-IV berturut-turut adalah 46,7829 $\mu \mathrm{m}$ menjadi 59,2423 $\mu \mathrm{m} ; 45,1385$ menjadi $56,4146 \mu \mathrm{m} ; 42,8431 \mu \mathrm{m}$ menjadi $54,5628 \mu \mathrm{m}$. Ukuran globul pada penyimpanan suhu $40^{\circ} \mathrm{C}$ (Gambar 4) pada formula II - IV berturutturut adalah 49,7716 $\mu \mathrm{m}$ menjadi $66,0909 \mu \mathrm{m}, 45,4780 \mu \mathrm{m}$ menjadi $62,1117 \mu \mathrm{m}, 43,5979$ $\mu \mathrm{m}$ menjadi 59,6487 $\mu \mathrm{m}$.

Peningkatan ukuran globul terkait adanya peningkatan suhu. Formula IV memiliki ukuran globul yang lebih kecil karena adanya lapisan polimer acrylates crosspolymer sebesar 3\%, dan viskositas lebih tinggi, keadaan ini sesuai dengan hukum Stokes.

\section{Hasil Uji Stabilitas Tipe Emulsi}

Formula II-formula IV pada penyimpanan suhu kamar dan suhu $40^{\circ} \mathrm{C}$ tetap memiliki tipe emulsi minyak dalam air. Komponen penyusun sabun emulsi berscrub ekstrak kulit batang nangka mengandung lebih banyak fase yang larut dalam air. Penentuan tipe emulsi dipengaruhi oleh pemilihan emulgator yaitu TEA-Stearat/TEA laurat yang merupakan jenis emulgator anionik yang larut didalam air sehingga dapat membentuk sistem emulsi M/A.

\section{Hasil Uji Stabilitas Volume Sedimentasi}

Formula II - formula IV pada suhu kamar ataupun suhu $40^{\circ} \mathrm{C}$ menunjukkan derajat sedimentasi dengan nilai $\mathrm{F}=1$ yang artinya, tidak ada penurunan atau pemisahan pada awal pengamatan sampai dengan minggu ke-4. Kestabilan ini berkaitan erat dengan penggunaan acrylates crosspolymer yang berfungsi sebagai thickening agent. Dapat disimpulkan emulsi didalam sabun emulsi berscrub ekstrak kulit batang nangka ini stabil secara fisik.

\section{Hasil uji stabilitas pH}




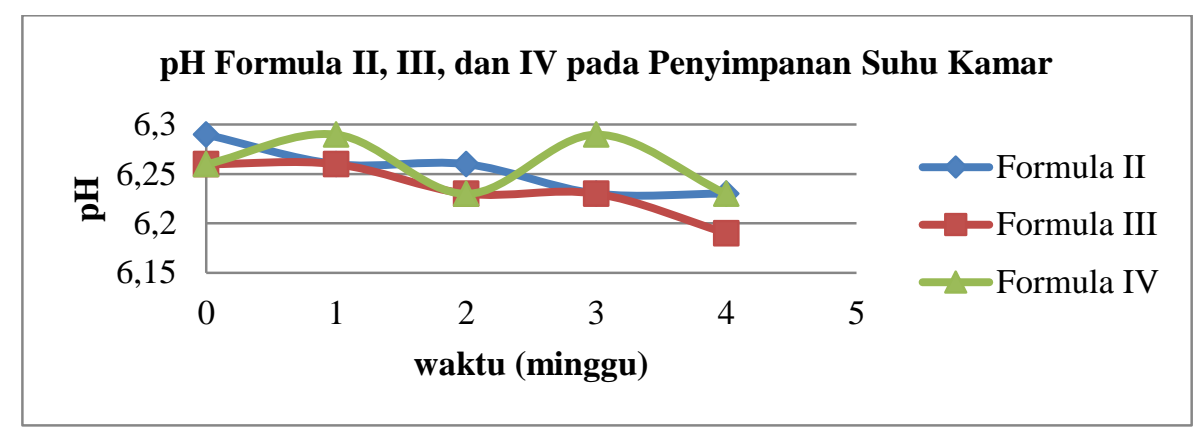

Gambar 5. Grafik hubungan $\mathrm{pH}$ terhadap waktu pada penyimpanan suhu kamar

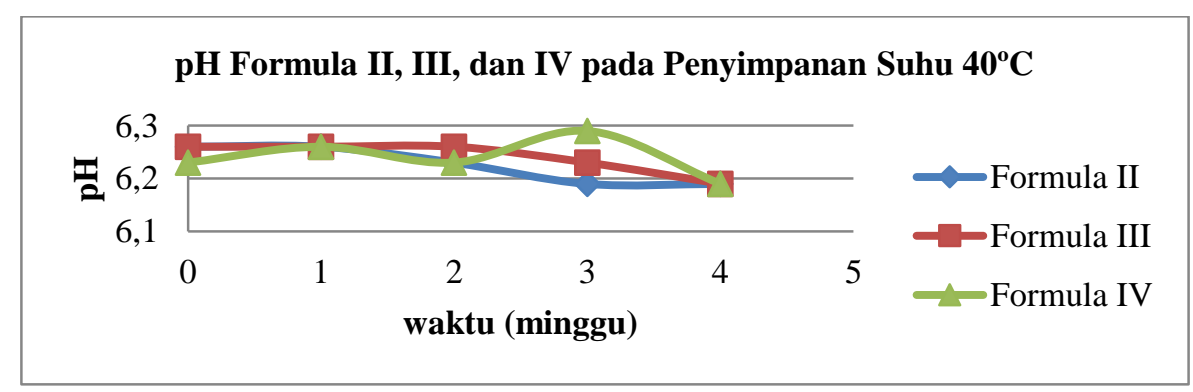

Gambar 6. Grafik hubungan $\mathrm{pH}$ terhadap waktu pada penyimpanan suhu $40^{\circ} \mathrm{C}$

Hasil penelitian $\mathrm{pH}$ yang disajikan pada Gambar 5 bahwa Formula II memiliki $\mathrm{pH}$ pada penyimpanan suhu kamar dari minggu ke-0 sampai dengan minggu ke-4 sebesar 6,29; 6,$26 ; 6,26 ; 6,23$; dan 6,23. Formula III sebesar 6,26; 6,26; 6,23; 6,23; dan 6,19, formula IV sebesar 6,26;6,29;6,23;6,29; dan 6,23. Nilai pH yang disajikan pada Gambar 6 pada penyimpanan suhu $40^{\circ} \mathrm{C}$ dari minggu 0 sampai minggu ke 4 dari formula II sebesar 6,26; 6,$26 ; 6,23 ; 6,19 ; 6,19$; formula III sebesar 6,$26 ; 6,26 ; 6,26 ; 6,23 ; 6,19$; formula IV sebesar 6,$23 ; 6,26 ; 6,23 ; 6,29 ; 6,19$. Berdasarkan hasil pengamatan bahwa semua formula mendekati $\mathrm{pH}$ ekstrak kulit batang nangka yaitu 6,18 dan berada dalam rentang $\mathrm{pH}$ kulit yaitu 4,5 sampai 6,5. Berdasarkan hasil statistika ANVA dua arah dengan aras kepercayaan $5 \%$ diperoleh bahwa tidak ada perbedaan bermakna $\mathrm{pH}$ antar formula pada penyimpanan pada suhu kamar maupun suhu $40^{\circ} \mathrm{C}$.

\section{KESIMPULAN}

1. Ekstrak kulit batang nangka dengan konsentrasi $2 \%$ dan Acrylates crosspolymer dengan variasi konsentrasi $2 \%$ sampai $3 \%$ dapat diformulasikan kedalam sabun emulsi minyak kedelai berscrub yang memenuhi parameter mutu fisik.

2. Sabun emulsi minyak kedelai berscrub ekstrak kulit batang nangka yang dihasilkan stabil secara fisik selama 4 minggu. Sediaan berupa cairan kental berwarna coklat muda beraroma parfum chamomile, tipe emulsi M/A, derajat sedimentasi 1, volume busa dalam air suling $72 \mathrm{~mL}$ dan pada air sadah $24 \mathrm{~mL}$. Tegangan permukaan $32,47 \pm 0,45$ dyne/cm; pH berkisar 6,26; bobot jenis meningkat dari $1,3055 \pm 2,01 \times 10^{-3} \mathrm{~g} / \mathrm{cm}^{3}$ menjadi $1,4873 \pm 2,46 \times 10^{-3} \mathrm{~g} / \mathrm{cm}^{3}$, diikuti dengan viskositas $7016,67 \mathrm{cPs} \pm 28,87 \mathrm{cPs}$ sampai dengan $8333,3 \pm 28,87 \mathrm{cPs}$. Sifat alir tiksotropik pseudoplastis untuk formula I dan II serta tiksotropik plastis untuk formula III dan IV. Ukuran globul menurun dari $46,7829 \mu \mathrm{m}$ menjadi $42,8431 \mu \mathrm{m}$.

3. Formula terbaik emulsi minyak kedelai berscrub ekstrak kulit batang nangka adalah dengan konsentrasi acrylates crosspolymer sebesar 3\% (formula IV). 


\section{DAFTAR PUSTAKA}

1. Chang TS., 2009. An Updated Review of Tyrosinase Inhibitors. Departement of Biological Science and Technology. National University Tainan Taiwan.

2. Juwita NK,. 2011. Uji Penghambatan Tirosinase dan Stabilitas Fisik Sediaan Krim Pemutih yang Mengandung Ekstrak Kulit Batang Nangka (Artocarpus heterophyllus) (Skripsi). Depok: Fakultas Matematika dan Ilmu Pengetahuan Alam Universitas Indonesia; h. 53.

3. Linda, 2012. Pengaruh Konsentrasi Acrylates Crosspolymer Terhadap Kestabilan Dispersi Butiran Scrub Polietilen di Dalam Sabun Emulsi Minyak kedelai (Glycine $\max ($ L.) Merr.) (Skripsi). Jakarta: Fakultas Farmasi Universitas Pancasila; h. 71-72.

4. Tranggono RI, Latifah F., 2007. Buku Pegangan Ilmu Pengetahuan Kosmetik. Jakarta: PT. Gramedia Pustaka Utama; h. 6-7; 21; 11-13; 27.

5. Gupta R, Mishra A, Kumar R, Prakash O., 2009. Artocarpus heterophyllus (Jackfruit): An Overview. Department of Pharmacognocy: Faculty of Pharmacy Babu Banarasi Das National Institute of Technology \& Management; Vol 3(6):353-358.

6. Arung TE, Shimizu K, Kondo R., 2006. Inhibitory Effect of Artocarpanone from Artocarpus heterophyllus on Melanin Biosynthesis. J Biol Pham Bull; Vol 29(9):19661969.

7. Departemen Kesehatan Republik Indonesia, 2000.Parameter Standar Umum Ekstrak Tumbuhan Obat. Jakarta: Direktorat Jenderal Pengawasan Obat dan Makanan; h. 2-12.

8. Baumann L., 2002. Cosmetics Dermatology Principles and Practice. $2^{\text {th }}$ edition. New York: The McGraw-Hill Companies; p. 3-11; 275.

9. Barel AO, Paye M, Maibach HI., (ed)., 2009. Handbook of Cosmetics Science and Technology. 3rd. ed. New York: Informa healthcare; p. 110; 769.

10. Rieger MM., 2000. Harry's Cosmeticology. $8^{\text {th }}$ edition. New York: Chemical Publishing Company Inc; p. 92-103; 485-98; 652-727.

11. Standar Nasional Indonesia, 1996. Sabun Mandi Cair. Dewan Standarisasi Nasional SNI 06-4085-1996. h. 2-8.

12. Umbach W.,1991. Cosmetics and The Toiletries Development Production and Use. $1^{\text {th }}$ edition. New York: Ellis Horwood Limited; p. 53-61.

13. Lachman L, Lieberman HA, Kanig JL., 1994. Teori dan Praktek Farmasi Industri. Edisi Ketiga. Vol III. Diterjemahkan oleh Suyatmi S. Jakarta: Universitas Indonesia Press; h. 1029-88.

14. Pramita W., 2011. Formulasi Sabun Emulsi Minyak Kedelai (Glycine max (L.) Merr.) Berscrub Dengan Variasi Konsentrasi Kopolimer Akrilat (Skripsi). Jakarta: Fakultas Farmasi Universitas Pancasila; h. 26-27; 89.

15. Rowe RC, Sheskey PJ, Quinn ME,( ed) 2009. Handbook of Pharmaceutical Excipients. $6^{\text {th }}$ edition. London: The Pharmaceutical Press; p. 45; 123; 177; 300; 654; 697. 